\title{
Gestational Labors: Care Politics and Surrogates' Struggle
}

\author{
Sophie Lewis
}

\section{INTRODUCTION}

A non-negligible fraction of human gestation has become professionalized. A sector of so-called "reproductive care" has fully emerged, whereby many wombs have entered the marketplace (Vora 2015; Pande 2015; Cooper and Waldby 2014; ICMR 2014). Far from stabilizing the meaning of "normal" reproduction, however, the exponential rise in surrogacy services is visibly troubling the systems determining what is called "motherhood". By extension, surrogacy publicity "causes trouble for the social relations of production and reproduction, which such mystification otherwise normalizes and conceals. Our task as thinkers of surrogacy, I propose, is not merely to explain but to "stay with [that] trouble" (Haraway 2011). As gestation has become paid labor, performed by a worker for a wage, space has appeared for scrutinizing these categories anew: a challenge that heaves up root ideological assumptions about motherhood and family. The surrogate becomes a potential subject of political rupture.

To point to how such a politics might be escalated, and what it might have the power to do, in what follows, I will question the technocratic distinction between surrogacy and pregnancy proper, which clearly

S. Lewis $(\bowtie)$

The University of Manchester, Manchester, United Kingdom

(C) The Author(s) 2016

S. Hofmann, A. Moreno (eds.), Intimate Economies, DOI 10.1057/978-1-137-56036-0_8 
naturalizes motherhood. The distinction, assumed to be self-evident, hinges on the downplaying of unromantic dimensions of pregnancy (such as pain and conflict) and, above all, on downplaying surrogates" creativity and political authority both as laborers and as prior mothers. I will also show how the majority of what passes for activist or political thinking on surrogacy ironically relies on truncated, technophobic apprehensions of capitalism, by which I mean an analysis which locates technology outside of the human body and outside of "nature", attributing to it the responsibility for (often gendered) forms of violence. Making mainstream sense of the practice of surrogacy also relies on a capitalist framework of reproductive normativity, which the surrogate-standing as she does both at the center of the conceptual cleavages mentioned above, and at the end point of a racialized, gendered, globalized process of neoliberal capital production-is a particularly well-suited figure to challenge.

For the purposes of this chapter, politics has been taken to mean the ensemble of practices which in some way aim at the composition of collectively livable life. When I speak of the potential for an affirmative surrogacy politics, I do not mean a juridical, legislative, bioethical or even analytic response to the facts of surrogacy. Rather, an affirmative surrogacy politics is the project of imagining a mode of collective, autonomous social regeneration, and appropriating, to that end, the technological means of doing "assisted gestation" (and-more broadly-care). Certainly, demands (e.g. for regulation) levied at the level of states, and transnational juridical bodies may become a first port of call for a struggle from below toward a way of enacting reproductive assistance that is both inherently just, and justly distributed. Here, however, an "affirmative surrogacy politics" points less at the pursuit of regulatory mechanisms and more at the self-organization of gestating together with others. I propose a normative pursuit of the conditions of possibility for ordinary people's collective and purposive reinvention of the mode of making children and, by extension, the world. These conditions of possibility are here suspected to include discursive interventions such as the recasting of surrogacy clinics as gestational workplaces (e.g. Lewis 2016).

\section{Reintroducing Baby Gammy}

The profile of marketized gestational surrogacy skyrocketed in 2014 when the case of "Baby Gammy" caught the attention of a global public. Today, Gammy is a child living in Thailand with Down Syndrome, while his twin, 
a so-called "healthy" girl named Pipah, resides in Australia (Marks 2015). In late 2013, Pipah's now-parents, the Farnells (a heterosexual Australian couple), commercially commissioned the pregnancy that gave issue to the twins. In so doing, they joined the many Australian tourists who had sought the pool of affective, sexual, or otherwise-reproductive labors that had been cheaply available in Thailand until the military coup the following year abrogated their flow. The Farnells' decision to hire a Thai surrogate echoed another, also geographically uneven, dynamic. Some onlookers speculated about the parallel informal intimate economy suggested by the couple's mere appearance (he is white, and she a Chinese-Australian). Sure enough, The Daily Mail unearthed evidence that David Farnell used a "mail-order bride" website to arrange the marriage in Jinxing. The woman later proved to be infertile, hence the turn to a California-based agency, Thailand-Surrogacy.Net, for further-biological-reproductive assistance. That visible sign, captured by the paparazzi, of an already-racialized character to Mr. Farnell's appropriation of reproductive supports throughout his life could only heighten the drama of villainization that erupted when Baby Gammy was "abandoned" (Marks 2015) in Thailand.

The martyred saint or "Mother Courage" within the tale was the surrogate employee of Thailand-Surrogacy, a young woman named Pattharamon Chanbua (Michael 2015). The multiple embryo transfer she underwent had resulted, as is common in commercial surrogacy, in the implantation of twins, which incurs a premium fee. Reportedly, late in the contract pregnancy, the Farnells were apprised by the clinic of the male fetal twin's Trisomy 21 (Gammy also suffers a congenital heart condition), and sought a partial refund, requesting that that twin be aborted, but Chanbua refused this option. Though it is somewhat unclear what Thailand-Surrogacy's position with regard to the late-term abortion was (disability is not recognized in Thailand as a legitimate ground for the procedure); another Australian couple at the time-who were infertile and desperate-claim to have received an email from the clinic that essentially offered them the disabled fetus for a fee (Hawley 2014).

While this evidence of "baby-selling" fueled several Australian TV features, further details of the backstory included further factors with equal "shock value". Mr. Farnell turned out to have a substantial criminal record of pedophilic abuse of girls, for which he had served an extended sentence in prison. (It is worth noting that a family member, not governments, brought the latter angle to light.) Once the media had gained their sensational arch-villain, then, Farnell swiftly became the symbol of an 
egregious departure from surrogacy ethics and violation of implicit unspoken norms governing the access to global care typically enjoyed by married, propertied, heterosexual white men. Accordingly, it became standard for journalists to cast the turncoat commissioning father of Baby Gammy as an archetypal danger to women and girls and perfect enemy of the institution of the family. In sections of civil society, too, as the various petitions to "Save Baby Pipah" (from him) made clear, Farnell became the very embodiment of the danger against which the normative value of family had to be defended.

Farnell's association with pedophilia detracted substantially from his embodiment of a particular approach toward begetting kin, whereby he had tacitly placed conditions on his future-oriented commitment to parent the products of a specific gestation (an attitude that is arguably not egregious, both within and without the overseas surrogacy industry). The brouhaha prompted myriad international calls for "regulation" of the surrogacy industry: the Sydney Morning Herald headline on August 10, 2014 "Thai surrogate Baby Gammy is a victim of an unregulated world" was typical of these. Rarely was it noticed that Baby Gammy was also the beneficiary of lack of regulation in the sense that, contracts having been easily voided, he could straightforwardly be integrated into the Chanbua family. Gammy was the catalyst for regulatory measures which, in turn, created unpleasant scenarios well into the following year.

Like many other babies, Gammy was brought forth amid a frantic and opaque touristic climate shaped by an ongoing military coup; in particular, a new regime directive on child trafficking that immediately required commissioning parents to obtain previously unnecessary release forms from their surrogates (Holmes 2015; Rawlinson 2014). In early 2015, it was widely reported that Baby Gammy had prompted the state of Thailand to ban commercial surrogacy altogether (Australian Associated Press, 20 February 2015). ${ }^{1}$ However, a backlog of already initiated gestational labors in Thailand resulted in an unhappy legislative endgame for transnational for-profit Thai surrogacy. For example, in July 2015, another couple was embroiled in a high-profile conflict over a contract brokered by the New Life clinic in Bangkok: the surrogate, having physically relinquished the baby, demanded it back, claiming she did not know the intended parents were gay (Holmes 2015).

Chanbua, for her part, never pronounced on the main subject of concern for onlookers - the commissioning father's sexual predilection and criminal past. From her perspective, the relevant events of 2014, in 
a nutshell, were that Gammy did not receive a lethal injection in utero, but was born alive, side by side with his sister. Subsequently, the Farnells changed their mind about not wanting Gammy; yet Chanbua refused their about-face and made a counter-threat of reclaiming Pipah. Gammy fell to the care of the poorer, geographically peripheral, racially other-yet by popular accounts fitter-putative parent. As such, the contradictions within the cry for regulation have been particularly glaring in this case. Although known as "Baby Gammy", the more substantial controversy surrounded the part of the surrogacy transaction that could be said to have gone smoothly, namely, Baby Pipah.

More regulation in surrogacy does not necessarily entail straightforward enforceability; in Israel and the UK, extra rules seek to allow limited forms of diversion from the initial agreement in a surrogacy (subject to change in parties' circumstances or, notably, the surrogate changing her mind). If a form of labor regulation were enforced removing all possible leeway around the devolution of custody following surrogacy, then, in this case, precisely the outcome that was popularly deemed unacceptable would have transpired: the ex-convict would have become enshrined as the parent of the male vulnerable twin also. However, the "unnatural" creation of kinin for-profit clinics is easier to mediatize than is the crisis of the "normal" and "natural" family. Far harder to mobilize around is the everyday violence that falls outside the purview of surrogacy: that between fathers and daughters or men and more vulnerable members of families.

Symptomatically, in the discourse around Gammy, the exact location of the perceived wrong was elusive, and non-specific to surrogacy. Implicitly it lay in the separation of the twins, the unsafety of Pipah in her Australian home and, simultaneously, in the relegation of the disabled male to the care of the person who insisted he be born; yet, also, in Farnell's presumption to procreate at all, that is, in the very origination of Pipah and Gammy, their very existence. Civil participants in the running commentary on Gammy-and the need for regulation he supposedly proved-rarely pronounced on how (for example) screening and barring a commissioning parent could be reconciled with the almost universally presumed "right to procreate". Absent from this discussion, then, was any widespread sense that bigger questions were appearing on the table-is procreation an intrinsic good? to whom do babies belong? how should humans be reproduced? what counter-acts gendered forms of power? - that were far more daunting than the simple moral framework of regulatory failure and egregious transgression implied. Such questions touch on the relations of 
the family in toto, exceeding in scope the minor role of the new reproductive technologies therein.

Gross surrogacy mishaps are not uncommon. The prolonged moment of extreme interest in the Gammy story, then, must be imputed to a mediagenic confluence of elements, including tangled markers of race, gender, and neocoloniality, but notably the specter of crisis at the heart of the family-in the form of middle-class suburban pedophilia. For comparison, a contemporaneous surrogacy scandal of far greater magnitude, involving a non-white member of the international elite, maintained a consistently low profile in the western media-its themes, though similar, proving less easily legible. Twenty-four-year-old Japanese business magnate and aspiring politician Mitsutoki Shigeta simultaneously employed at least 11 Thai surrogates with different agencies and was said to be envisioning these children as a future political voting bloc for himself (Rawlinson 2014). Shigeta, a single man, clinically fathered at least 16 babies in 2014: prompting a raid by Interpol, yet eliciting only surprisingly restricted debate about limits to the "right to procreate". Reference to Shigeta serves in this context to contextualize Baby Gammy and indicate that his case was not the only available lightning rod for global concern around Thailand's surrogacy industry, but rather, one whose characteristics were perhaps more likely to circumscribe the political questions it was able to generate.

\section{Responsibility and “The Family"}

Since biogenetics distanced Chanbua, and her pre-existing family, from Gammy, the decision to care for Gammy was more visible as a decision. It generated belonging and "responsibility" in the sense vindicated by Donna Haraway of responsive attentiveness to a stranger, other or kin (Haraway 2011). Whether Gammy is "hers" or not was beside the point, in this view. As Haraway says on the theme of surrogacy, "The point for me ... is parenting, not reproducing. Parenting is about caring for generations, one's own or not; reproducing is about making more of oneself to populate the future, quite a different matter" (2011). Given that birth has typically been the marker of individual humans' genealogies and positions within families and racial hierarchies, the rise to prominence of bodies-in-labor whose babies are not racially continuous with themselves-nor kin-introduces new subversive potential to the scene of global reproduction. "The Surrogate remains a creature that nourishes indigestion" (Haraway 2011). 
Chanbua's partner was evidently happy to become a surrogate father, and he was not the only one in the extended Chanbua family to adopt this stance. Their embrace was not where Gammy had been intended to belong, despite his bodily continuity with Pattharamon's body. Thus Gammy's fame was that of a global pseudo-orphan, out of place. As the above photograph suggests, the perceived fragility of Baby Gammy - whose need for medical care inspired thousands of charitable donations-was derived in part from his relative whiteness, which emerged from the brown flesh of an Asian woman and, by achieving high global visibility, could not but elicit anxiety in its apparent threat to the social construction of race. Pregnancy's historically fraught yet unavoidable role in eugenic delineation and the policing of class property as well as race boundaries is well-documented in the canon of critical race theory, on which some of the most thoughtful contemporary theorists of reproductive technology fruitfully draw (Vora 2015; Rudrappa 2015; Banerjee 2014; Roberts 2009). The new race-critical and de-colonial geographies of gestation, by heightening many of the contradictions that ideologies of "family" seek to resolve through pregnancy, offer fresh opportunity for a struggle over care. The starting point, to adapt a famous slogan of post-colonial insurgency and self-affirmation, might be: "Your children are here because we are there".

While Chanbua's image was partially sanitized, her undertaking of responsibility for Farnell's biogenetic property, deemed the defective by-product of her body's work, was still a somewhat indigestible act. In performing it, Chanbua interpreted the gestational labor that she had performed as a ground for an affirmative politics she did not choose to couch in racial terms - though its freight was anti-racist. Foremost for her seem to have been qualitative questions to do with intimate care for disabled children, whereby the prerogative to mother him hinged on responsibility, more than race or genetics. Her narrative, in fact, introduced qualitative and tacitly political dimensions that complicated the dominant story of Gammy's abandonment by his genetic proprietor(s). The BBC reported: "in an interview ... Pattharamon Chanbua, 21, appeared to backtrack, saying: "I did not allow Gammy to go back with them-that's the truth. It is because they would have taken Gammy back and put him in an institute'" (11 August 2014). She also told the Sydney Morning Herald: "I would like to tell Thai women-don't get into this business as a surrogate. Don't just think only for money-if something goes wrong no one will help us and the baby will be abandoned from society, then we have to take responsibility for that" (Murdoch 2014). 
Tantrums were triggered: at the scandal's apex, the CEO of Thai Surrogacy, just one of many companies the Farnells could have used in or around Bangkok, alleged that his also-Chinese wife had yelled at Mrs. Farnell that "they must take responsibility for the baby" (Hawley 2014). Global opinion ruled, however uneasily, against Gammy's best interests lying in Australia. Despite being visibly overwhelmed and to some extent drowned out by the media's ventriloquism of her, Chanbua could-when pressed-articulate a logic, undergirding her sense of where, how, and with whom Gammy should live, which contained elements of a non-proprietary vision of parenting. Her stance evoked solidarity with the newborns against the individuals who had commissioned them into existence (by buying her embodied labor-power), a subversive twist on classical maternity. As such, she conveyed the germ of the possibility of determining carers and infants' interests in common, instead of by exclusive reference to ownership and entitlement. In this, the reproductive surrogate was also centering herself, the definitionally marginal or proxy figure, in the decision-making.

The figure of the renegade surrogate-who has ideas of her own about child-rearing, breaks the terms of her agreement with the commissioning parents, and can be imagined, at worst, absconding with the baby she carried for other people-has presented a frightening challenge for the commercial surrogacy industry ever since the disastrously public and litigious case of Baby M in New Jersey, which exclusively involved locals. In 1986, the surrogate Mary Beth Whitehead changed her mind and staked a claim as the genetic mother (this practice of using the surrogate's egg, called traditional surrogacy, was the norm for surrogacies at the time). Baby $\mathrm{M}$ divided both court and public opinion, even sparking a national antisurrogacy movement (the National Coalition Against Surrogacy) which had international support (e.g. FINRRAGE, the Feminist International Network of Resistance to Reproductive and Genetic Engineering; National Coalition Against Surrogacy). Almost 30 years later, commercial surrogates are typically not members of the same community (or even nation) as clients. That parties occupy different class positions is tacitly written into the exchange of money for procreative labor-power. ${ }^{2}$

The stark socioeconomic gulf separating the Farnells and the Chanbuas ensured that the "Gammy" arrangement resonated in many people's minds in its immediate resemblance to sexual and domestic service labor markets in the Pacific that are predicated on extreme inequalities. Clinicians combined Mr. Farnell's sperm with anonymously donated oocytes, meaning that Pipah and Gammy did not bear any genetic material of the intended 
mother, Wendy, any more than they did Chanbua's. Thus, in signing up to bring the twins into being, both women were undertaking care commitments grounded in labor (gestating and parenting) rather than biogenetics. The unknown third had performed the "clinical labor" of donating her gametes. This intimation of a form of double or triple surrogation of Asian women's reproductive labors - in Mr. Farnell's home and family life-rewards scrutiny. It epitomizes an economic trend that has been identified by Melinda Cooper and Catherine Waldby as the deepening partitioning and marketization of certain bodily labors typically performed for free in the private domain (Cooper and Waldby 2014).

Noting this still leaves open, however, the question of the political purport of this increase in commercially outsourced and waged social reproduction. It has been my contention that Chanbua provided germ of an answer, her words threatening more than just the conscience of would-be genetic parents everywhere who may-reasonably_experience anxiety as to whether the whiteness of European babies who emerge from waged wombs abroad is real (Gusmaroli 2015). Chanbua captured the dual character of care-as work and love-that was, for autonomist feminists, the source of its potential mass class power. According to the 1970s Italian exponents of the Wages For Housework (also termed Wages Against Housework) campaign, both the wage and the demand for a wage could serve to make women's so-called "labors of love" visible as work and form a common platform geared toward the collectivization of socially reproductive life. Adapting the Wages Against Housework perspective, then, to contemporary surrogacy context, one might say: contract pregnancy or home pregnancy, "[e]very miscarriage is a work accident" (Federici 1975).

\section{The Stakes of Seeing Surrogacy as “Just” Gestation}

Gestational labor cuts across boundaries defining work and non-work, or kinship and everyday living on the one hand and the professionalized biomedicine dealing in "life itself" on the other (more on the latter later). Gestation, reflecting this internal dichotomy, becomes an oddly queer process when scrutinized closely, being both conscious and unconscious, labor and life, care and growth, nature and creativity, technology and flesh, metabolism and art, and production and reproduction (Lewis 2015). An apt source of metaphors that sometimes obscure more than they reveal, gestation perversely straddles crucial conceptual cleavages: public/private; 
intimate/economic; productive/reproductive; conscious/unconscious; imaginative/animal; creative/passive; intentional/unintentional; even, since the rise of In Vitro Fertilization (IVF) in the late 1960s, hybrid/ organic and vital/artificial, human/nonhuman. Pregnancy is the site of enormous more-than-human power. As excitement about womb transplants and technoutopian fantasies about ectogenetic incubators make clear, it is also the object of inestimable societal anxiety.

Presently, surrogacy functions as a domain separate from free, so-called "normal" gestation and motherhood, rather than as an extension of gestation's internal organization that reflects back on that "natural" state of affairs. However, the very fact that it is the gestator, rather than the person who steps in to be the parent, that is indexed as "surrogate", is wholly contingent on narratives of biogenetic property in the family, narratives that can be changed (Strathern 1992; Roberts 2009). Kalindi Vora is one of the few scholars who make the conceptual leap of looking at mothering through the lens of surrogacy, rather than vice versa. For Vora, the productive character of the work of mothering ought to become "more visible when viewed through ... commercial surrogacy" (Vora 2009, 266). Certainly, the surrogacy/motherhood distinction is a powerful social construction, but cases like Gammy's show that it is only contingently based on the factuality of a biomedical expert's guarantee that one is making more of oneself (as verifiable by DNA testing). When needed, exceptions can be made in what makes something surrogate. The natural motherhood of a "gestational carrier" can be reinserted if, for example, the baby is unwanted: this cunning tactic of neoliberal society was the basis of Chanbua's public anti-patriarchal complaint "no one will help us".

Fundamentally, a surrogate, much like a wet nurse or nanny, is contractually obliged to care for a child, yet prohibited from harboring any excess desire to care for it independently. Departure from that Janus-faced script has the potential to elicit censure and backlash; as can, paradoxically, adherence to it-where seamless service is interpreted as callous babyselling. Chanbua's public relations success presents suggestive indications about our society's anxious arbitrage between surrogates who deserve pity or "rescue". Gammy's fate, in the public eye, fell between a victimized brown woman and the predatory white pedophile who had not only "bought" Gammy, but also cast him aside. A vociferous assertion of the innocent surrogate's status as mother arose within a briefly viral campaign which invoked ostensibly contradictory tropes of saintly or heroic exceptionality, on the one hand, and a so-called natural mothering "instinct" on 
the other. As this strangely bivalent response suggested, the job Chanbua performed was in one sense uniquely remarkable (as described above) and, in another, banally universal. Her motherhood was supposed to end with parturition, and instead, it began at that point, anew. As such, Gammy starkly embodied the disquieting possibility that newborns are all aliensalienated products of gestational labor-who require conscious adoption, reappropriation, and care upon their exit from their unity with the mother's flesh (Lewis 2015). In the neglected thought of philosopher and midwife Mary O'Brien, all pregnancies contain this mix of singularity and generality, contingency, and historicity, through which gestators intrinsically exceed the bounds of "male-stream thought" (O'Brien 1981, 30).

The terminology of the surrogacy industry is a suggestive field for political appropriations and détournement by surrogate workers. For exampleas noted above - the term distinguishing itself against the 1980s praxis of traditional surrogacy is "gestational" surrogacy. With the latter method, the surrogate's ova are not employed, such that the renegade surrogate can more easily recede in clients' imaginations, not least because the racial frontiers and geographic distances between commissioning parents and the surrogate's body have thereby been enhanced and securitized. Those whose bodies and whose labor have fulfilled a given procreative purpose, however, can easily inconvenience this implicit logic with reference to both experience and science that defies such borders. "It's my blood even if their genes" said one surrogate interviewed (Pande 2015, 148). Indeed, cells pass in both directions between any given mother and her fetus; articles raising awareness of this phenomenon (called "micro-chimerism") are increasingly prevalent (e.g. "A Pregnancy Souvenir: Cells That Are Not Your Own', New York Times, 10 September 2015).

Geopolitical anomalies such as Gammy bring to light this radically unromantic, unpretty, and unruly side to gestation. They point to the delusory nature of biogenetic securitization and to the potential limits of a global public's acceptance of the discursive subordination of gestational laborers who are surrogated in the service of others. The ability of contemporary reproductive markets to endure multiple such challenges and exceptions may be weaker than it appears. The historical test of this would be the difference between intentional, conscious, and collective action by surrogates, and these isolated reactive moments. Through these briefly available windows, when surrogacy becomes a controversy, it also becomes easier to see attempts at circumscribing the care politics that could erupt from this field. To recall the delusional phrase used by an 
English commissioning parent (quoted in The Daily Mail in 2012) of their Asian surrogate, the hope of those surrogating their reproduction is that: "she is just the vessel". ${ }^{3}$

\section{REPRO-NORMATIVITY AND TECHNOCRACY}

Capitalist biomedical technocracy, particularly in its highly gendered manifestation as above, presents a formidable barrier to apprehending the possibility of self-directed, conscious, and collective gestation. The industry goes by the name "assisted reproductive technology" where, by being assimilated under the rubric of technology, the meaning of surrogacy can, theoretically, shed all traces of pain, mutual uncertainty, and messy relationality. It becomes a package of "reproductive care" delivering a clean technical solution to the pathology designated "infertility" (e.g. Wendy Farnell's).

But this "technology" framing arises most decisively within the most value-extractive, slum gestational economies, which is to say, in so-called medical tourism and not so prominently in the UK, Israel, or the USA. For example, India has long provided the global middle class with one type of "tech support", and today, it positions itself as the destination par excellence for medical troubleshooting as well, boasting prices that "democratize" access to procreative assistance (Fixmer-Oraiz 2013, 138). Indian surrogates themselves may conceptualize their activity as God-given and kinship-forming (see Vora 2015, 120-128); but their managing clinicians do not. Inside the USA, by contrast, commercial surrogacy freelancers have established a quite different discursive arena in which the spiritual predominates over the technical, whereby they, as "surro-mamas", can enjoy privileged status as powerful beings and honorary family members. To these surro-mamas" central and almost spiritual creativity, the medical technology appears as purely auxiliary (Berend 2012). This tells us that understandings of gestation are shaped, racialized, and malleable.

Another ideological barrier to surrogate politics is equally formidable. In 2001, Katherine Franke coined the term "repro-normativity" to describe the social forces that incentivize motherhood to the point of pathologizing women who live non-reproductive lives. Franke, making a plea for the cultural de-centering of reproduction for its own sake, wrote: "the fact that the future of the species depends upon ongoing reproduction does not relieve us from devoting critical attention to the manners in which this biological demand becomes culturally organized" (Franke 2001, 186). 
Why have a baby? Why ensure a baby is "one's own"? It is remarkable that surrogacy's public life-viz Gammy-frequently closes down, rather than opens up, questions about the fundamental assumptions structuring family intimacy and culturally organizing the very appetite for babies. Yet it is my contention that, in the field of surrogacy scholarship, we have also proven for the most part reluctant to challenge the repro-normativity of the industry. This particular reluctance can be partly attributed to a progressive embrace of surrogacy's affordance of genetic family ties to some people-Lesbian/Gay/Bisexual/Transgender (LGBT), infertile, of postreproductive age, or otherwise reproductively non-normative-who had not been able to create them before. A critique of patrilineal attachment to guaranteed parentage seems to fall short in the face of a desire for "more of oneself" that is increasingly brought to the market by women and queers. Yet non-heterosexual clients still make up a minority of clientele in reproductive markets, and if there is one thing the blissful imagery on surrogacy websites unfailingly communicates, it is uncritical promotion of biogenetic reproduction for its own sake. The infertility specialists tap the deep roots of repro-normative psychology as they whisper "Don't you want one?" via a thousand websites. How can one argue with the birth of a baby?

What is a baby: a crutch, or a sort of project involving nurturing a helpless stranger? Fetuses are always genetically different from the bodies they inhabit; and for their part, grown bodies are not discriminatory about the embryos they will accept for uterine wall implantation. It follows from this little-explored reality that stressing the material continuity between surrogate and "straight" gestation makes a good de-mystifying strategy, a form of knowledge counter to the self-evident and naturalized certainties of contemporary repro-tech. Performing an only semi-conscious yet fully creative labor, the surrogate worker manages the remarkable alchemy of growing an "alien" fetus insider herself (Majumdar 2014). Yet surrogates are rarely asked whether they also experienced their prior ("natural") pregnancies as alien (Israeli practices are a notable exception cf. Teman 2009). In typical for-profit surrogacy clinics, rules exist stating that the gestation must not be her first (this "proves" prior fertility and supposedly decreases the risk of counter-contractual bonding). The surrogate occupies the only truly authoritative position from which to judge the distinctiveness of the experience of bodily unity that links her with an "alien" rather than with kin.

The cyborg spectacle of a helpless squalling creature that is destined to become (for example) a white Australian citizen, yet is emerging from a 
dark-skinned body in Thailand, is surely one of the clearest lenses through which to view the technonatural character of the human. The obvious artifice of surrogacy, together with the occasional baby on a "white" trajectory who ends up staying with a brown family, shows the contingency of the human body's naturalization and socialization within various global matrices of power and entitlement, belonging and otherness, and humanity and surplus. In order to be optimistic about the transformations that are possible here, one need not collude with the types of romanticization of the surrogate- often as a remote handmaiden figure, sometimes as ultimate selfless mother-that is (usually) performed by grateful parents for whom a "surrogacy journey" has gone well. Reading the terrain of surrogacy in a de-naturalizing and politicizing mode connects us, potentially, with the world beyond capitalist reproduction that some surrogacies allow us to glimpse. By questioning how different the stakes of "normal" or "straight" reproduction actually are, one can aim to assemble theoretical tools for a far broader politicization of social reproduction.

An affirmative politics of surrogacy, simply by raising and making the embodied person of the surrogate matter, is necessarily disruptive of the baby-centric, technocratic, and repro-normative organization of most gestation today. Within present conditions of welfare retrenchment, austerity, and a resultant deepening of reproductive crisis, the unrecognized laborers who are engaged in commercial and lay pregnancies alike could experiment with a mothering strike, demanding "wages for pregnancy", "wages for mothering" together. Such a politics would have to soberly confront the material parameters of the reproductive workplace, which are potentially necropolitical. It would have to de-center the claims of both clinical bosses and genetic commissioners on the contents of the laborer's uterus. Being able to contemplate the possibility of withdrawing the life-giving labor involved is as important as breaching contract by refusing to terminate pregnancy, as Pattharamon Chanbua did, on an occasion where it is the continuance of gestation that is against the other stakeholders' wishes.

If every miscarriage is a workplace accident, every abortion is potentially a labor dispute. As we saw earlier, gestation and surrogacy are separated only by a name and a choreography, the external technological components of any surrogacy process being merely IVF and embryo transfer: procedures which, in reality, are less sophisticated than methods commonly used in livestock agriculture. (Indeed, for some anti-repro-tech activists, the development of techniques on nonhumans in livestock breeding scandalously revealed the dehumanizing eugenic agenda behind surrogacy.) 
If mechanically inseminating a woman with gametes that were mixed in a Petri dish is technology, then so is cooked food (Haraway 1991). And so, by extension, are all of our bodies, which are best thought of not so much as discrete human selves but as cyborg hybrids, part machine and animal, that are hopelessly and liquidly inter-imbricated with our virtual and organic environments, helping sustain other "bodily natures" (Alaimo 2010). From this point of view, there is nothing normatively unpalatable in remarking that surrogates themselves co-constitute the embodied technology of baby-making. The technology is $u s$.

\section{Beyond Technophobic Anti-Surrogacy "Feminisms"}

For certain activists in the field of surrogacy feminism, however, this technofeminist tendency has been anathema. Feminists of FINRRAGE founder Renate Klein"s persuasion have persistently deemed reproductive technologies to be tools necessarily wielded by the enemies of "women". FINRRAGE commonly disseminated phrases like "Test-Tube Women" in the 1980s, by way of preface to the implicitly shocking question "What Future for Motherhood?" —as in the 1984 book by Klein. To them, the intrinsically degrading properties of IVF, embryo transfer and surrogacy would inevitably lead to these technologies being purposed-if left unchallenged-toward the engineering of greater inequality and alienation for the global oppressed sex-class. The meaning of technology, to these figures, was in almost all cases an unconscionable, masculinist colonization of life. As such they pitted their ideal of a female sisterhood "freely" exercising its biological autonomy against the deeply undesirable historic rise (as they perceived it) of "The Mother Machine" or "Man-Made Woman" (to paraphrase other popular book titles by FINRRAGE affiliate Gena Corea, published 1985, 1987). In the eyes of the network, it was in the power of "reproductive and genetic engineering [to] dismember, fragment, and dissect women into their body parts"- "reducing them to matter" (Klein 1991:394).

Notwithstanding contemporaneous critiques of this understanding of matter-by Haraway, Sarah Franklin, and others-substantial surviving elements of this sensibility still circulate in the twenty-first century. In the sphere of juridical and bioethical philosophy, proponents broadly within this trend ponder largely unhelpful questions, for example, "Is Women's Labor a Commodity?" (Anderson 1990)—the answer proposed is that it ought not to be-or "Transnational gestational surrogacy: does 
it have to be exploitative?" (Kirby 2014)—where exploitation is a moral concept rather than the name for any confrontation between capital and the wage - and so on. Ironically for a form of feminism, these positions are built firmly in a repro-normative framework, because they assume that gestating genetically unrelated embryos destined for other communities is something women would not, could not, consent to do.

Continuing the influential early vein of anti-surrogacy thought, the strategic deployment of words like "machine", "incubator", and "oven" remains a standard way of vilifying surrogacy practices and exposing its supposedly inherently dehumanizing ("anti-woman") logic. Calls to arms sometimes reprise the FINRRAGE perspective almost word for word: "It's dehumanizing to be "an oven" for someone else's baby" (The Observer, 9 May 2015); "a twisted version of slavery ... . It devalues life" (The Guardian, 4 August 2015). The 2015 inaugural press statement from the Stop Surrogacy Now network, which bears many FINNRAGE signatories and seems poised to replace FINRRAGE and revive anti-surrogacy feminism, includes the quote "A woman is a human being, not a machine".

Intuitive as this analysis can seem, it belongs to a broad tendency to truncate anti-capitalist thinking by regarding some forms of labor exploitation as morally unique and deserving of elimination by any means (implicitly, from above). When operating as a form of feminism, this tendency often targets certain intimate corporeal forms of work, notably, sexwork and surrogacy, identifying them as commodification of the person, and calling for their abolition on that basis. Making an analogy between surrogacy and the sale of sex, both of whose anti-dignity implications are taken as read, forms the foundation of contemporary campaigner Kajsa Ekis Ekman's perspective-as laid out in her book Being and Being Bought (Ekman 2013). Ekman repeats the basis of Gena Corea's denunciations of "reproductive brothels" in the 1980s, which had already echoed in myriad other FINRRAGE-affiliated publications. What the gesture assumes is that metaphorically identifying commercial surrogacy with "reproductive prostitution" constitutes, not just an analytical, but a pre-evident normative contribution in itself.

In other words, what it means economically and, by extension, politically, to work as a reproductive prostitute (beyond the bare fact that it is, in their view, very bad), remains unspecified. The precise content of the difference between paid and unpaid forms of sexual and reproductive labor, for example, between "normal" and surrogated pregnancies, is left disappointingly uninterrogated in these analyses - as they are in the 
similarly technophobic ecofeminism of Maria Mies and Vandana Shiva, which asserts that "reproductive technology alienates both men and women from their bodies" (Mies and Shiva 1993, 141). Valuable as much of these players' advocacy is on other fronts, their anti-commodification stance rises to the defense of an essential, organic, unalienated (propositionally female) human body which can never exist and, in any case, does not emerge from an inquiry into paid reproducers" experience of their workplace.

Technophobic anti-surrogacy feminisms typically announce their opposition to "objectification", animated by the specter of the use of poor and working class women as "parts" and "breeders". Unfortunately, however, this approach immediately falls into the reification of surrogates itselfthis time in apolitical categories such as victimhood, martyrdom, or sainthood. The short-circuit stems from a common political failure, namely the partial inability to distinguish one's rhetorical strategy from one's applied analysis. A surrogate-led mobilization would not seek to "save" surrogates from their livelihood and, by centering surrogates, would necessarily require acceptance of the "cyborg" conditions of embodiment in which we are always already embroiled-this being a pre-condition for transforming those conditions.

Strategically, anti-surrogacy activists isolate the-growing-marketized section of biological reproduction as their site of resistance and refusal. At this juncture, however, their distrust of technology leads them, even if unintentionally, to withhold a respectful, comradely, and solidarity-based politics from surrogacy workers. Contra to the politicization I wish to abet, their flattened constituency ("women") seems to underspecify who the subjects of this unlivable present are, who can fight to make it livable. On the terrain of surrogacy, the question should be: how will surrogates struggle? How will paid reproducers struggle in common with mothers, carers, and wives? But these are questions that are, for the most part, omitted.

Gestational contracts do involve a penetration that is capitalist: by relatively powerful individuals, both materially and abstractly, deep into the body of a less powerful person. Unlike the cleaning contractors who sweep repro-tech clinics, or the migrant care-workers who may serve later as au pairs to the babies who are born in them, surrogates (who come from broadly the same marginalized classes as these) perform a labor that is "fully internal" to the value chains of the biomedical industry of fertility medicine (Cooper and Waldby 2014, 9). Nevertheless, to rhetorically 
identify a surrogate with an "oven" is too easy, in particular in the absence of any theorization of what she would otherwise be (indeed, simultaneously is) in other (e.g. unwaged) spheres of life. It is therefore to deploy technophobic scaremongering to shame those responsible for women "renting" their wombs-a group which includes the women themselves-thereby foreclosing politics that truly includes them. This subtly but perniciously patronizing epistemic orientation toward gestational labor sometimes rears its head more directly: for example, Ross-Sherriff considers it worthy of note that studies were conducted using "standardized psychological tests [and] found that ... surrogate mothers in Great Britain and the United States were self-sufficient, nonconformist, and independent thinkers" (Ross-Sherriff 2012). Presumably, the intended audience expected something less from "reproductive prostitutes" and/or "ovens".

The global divisions of labor that structure commissioning parents' access to procreative assistance are unjust relations of bioavailability; by their very logic, they exploit and amplify a stratification. Yet, the division can only be thrown into question from a perspective that refrains from identifying the bodies of the bioavailable with the people in question and from determining those people's best interests for them. Surrogates, in their own estimation-or so several ethnographies have found-work hard, physically and affectively (Pande 2015; Rudrappa 2015; Vora 2015). It is not without irony, then, that those who contemplate saving surrogates from their livelihood deny its status as work. In doing so, they become complicit in enabling the neoliberal, anti-political, technical framing of surrogacy on which the discreet and individuated channels of so-called "donor" economies depend.

De-stratifying reproduction implies refusing the sanctity of genetic property, as genetic property is the basis upon which intended parents effectively own a part of the surrogate's body and have the right to determine its fate. But de-stratifying reproduction implies above all a process of dispute, emanating from workers themselves whereby, if the encroaching tide of commodification of reproduction is denounced, then it is denounced because it erases the self-autonomy of bodies to an unacceptable degree, not on the basis of an exceptionalist argument that abstracting reproduction from all other social relations of work.

It is undesirable here to over-privilege gestational agency, for instance by inverting the gestationally passive-exclusively genetic-account promoted by surrogacy clinicians for their customers' benefit. This would amount to participating in a reductive and, anyway, ultimately false 
authorship dispute over an infant (gene vs. gestator), which is hardly conducive to an anti-proprietary and common reinvention of the "family". The point in referencing the more-than-human, cyborgian surrogate, rather, has been to evoke a vision of mothering in which reproduction is vibrantly creative and alive, yet unromantic, unpretty, and de-centered in relation to other acts of mothering. The point has been to try to evacuate the myth of normal or natural gestation from the conversation, along with the myth of a normal of natural human body that untouched by the scientific shibboleth we call "technology".

Some not insignificant differences exist between the components of the labor performed by many present-day surrogates and other "naturally" pregnant women around the world. While all pregnancies are subject to a matrix of technological and governmental involvement, surrogates forfeit a greater degree of control, comply with a more rigid dietary discipline, and typically take up full-time residence within the clinical complex. At the same time, it bears spelling out, in the context of surrogacy discourses in which it seems taboo to say so, that the core of what takes place in surrogacy is no more nor less than human gestation. No more nor less technological, it is substantially the same thing. The gestating body, as we have seen, is not overly fussy about an embryo's genetics because it is always already substantially "alien". The aim in stressing this is to think through the consequences of that insistence from both the surrogates and non-surrogates" standpoint (one person very often unites both perspectives), and then to explore how such consciousness can be generalized.

The distinctive feature of the surrogate-fetus nine-month presence in the worker's anatomy is not so much its genetic difference as the fact that its path toward viability is progressively captured as profitable work. Profit can be derived from the sale of individuals" gene actualization, but this depends heavily — at the level of symbolism — on a false guarantee that the buyer's baby will not emerge to greet them full of somebody else's blood and guts. Yet, surrogacy being simple pregnancy, the baby always does greet you that way. After all, the surrogate's placental surfaces are what made the infant. The surrogate stands in, both symbolically and materially, for an absent gestational capacity in other people. And the fiction of surrogacy is that this connection is just as temporary as the disconnection (sitting out) of the surrogate from her own family during the process. Surrogate-ness, then, is above all else a disavowed social relation, a surplus on which one can capitalize. 


\section{Conclusion: Is "Life Itself” Strategic?}

Arguably the most common trope found in both promotional schmaltz and disciplinary apparatuses around surrogacy is giving the gift of life. "Life" in this context evades definition even as its creation is enshrined as humanity's ultimate, ineffable, supremely rewarding raison d'être; so the above discussion of repro-normativity also noted. The affordances of "the gift of life" have been amply explored, for instance by Pande with respect to "gifts for global sisters" (2015) and in the work of Heléna Ragoné (2003).

From here it is only a small step to the matter of Nikolas Rose's influential monograph on biopolitics The Politics of Life Itself (Rose 2007) which formed the starting point for Cooper and Waldby's Marxian analysis. In the pages of Clinical Labor, "life itself" is a material and mechanical substance undergirding the value-forms of the contemporary bioeconomy (Cooper and Waldby 2014). Theirs is a risky strategy because, within infertility medicine, and sometimes its attendant critical scholarship, its invocation serves only to mystify. When the commodity produced by surrogacy is referred to as this formidably de-politicizing substance "life itself"-and this may be spurred by a desire not to say babies- the effect can be to disempower its makers and to resegregate them away from the other labors that sustain life-in-general, such as everyday housework. Rudrappa (2015) conjures the advent of "markets in life itself" while Vora's analysis uncovers flows of "vital energy" (Vora 2015). While neither analysis comes close to abstracting reproduction from other social relations, reference to vitality seems preferable to "life itself" in that it seems loosely quantifiable and thus more open to the qualitative transformations that forge our life-in-particular.

The professionally pregnant are, today, far from being positioned as experts on life's production and distribution. In fact, where "life itself" is explicitly in play in the same context of the womb, politics risks disappearing into a vortex of the arcane. Nathan Stormer argues convincingly that the dominant, sublime aesthetic within visualizations of gestation, which feature individuated human embryos floating as though in space, is a zone in which we have been trained to "look in wonder" at a "normal miracle"-namely, the miracle of life itself (Stormer 2008:667). In the face of "life itself", none of us can be pragmatic, syndicalist gestators: rather, we are all more or less equally deprived of knowledge and wonderstruck, except perhaps for scientists. But this can change. As we have seen, it is 
gestational laborers who produce the commonplace life and-contra- to repro-normative dogma-this need not inspire grandiose talk of miracle. Lives, rather than life itself, are what matter; lives are where suffering and struggle occur. Admittedly, there are scholars who declare themselves optimistic about a "politics of life itself". 4

If "life itself" really possessed politically unifying power, then the poor, low-caste, and racialized communities where medical infertility is most prevalent, and the queer and trans communities where non-reproductivity is destiny, would be priorities within the cultural apparatus of assisted reproduction. Instead, historically, we find assaults on these communities extending even to sterilization drives, and we see that allocations of subsidies for overcoming infertility are racialized in favor of whitenessparticularly when mediated via the institution of marriage (Banerjee 2014; Roberts 2009). In contemporary society, "life itself" stubbornly persists in manifesting not as a leveling force but as a striated, highly hierarchized category, much akin to the falsely universal idea of the human. "Life itself" is most often invoked within individualistic discursive fields, for instance, when intended parents announce that they love or plan to love the child of their own "more than life itself".

Whether most people love life very much is an open question, given the broadly abject, alienated, and immiserated condition of much existence in the twenty-first century, in which having children so often seems like the only available solace. Despite the evident claims of LGBT people on the provision of state procreative infrastructure as a form of welfare, the really pressing project for progressive communities at this juncture is not the project of passing on life but that of determining to render life in particular worth living. This endeavor is a very different matter to the preservation of life for its own, or indeed any individual's, sake.

In her history of the body and primitive accumulation, Silvia Federici remarks that during the Renaissance "male doctors came to be seen as the true "givers of life" (as in the alchemical dreams of the Renaissance magicians)" (Federici 2004, 89). An aftertaste of this legacy from the early modern professionalization of reproduction is still with us today. It is visible within surrogacy in the guise of a gene-centric technocracy that pretends experts are responsible for the gestational labors performed by women. Today's doctors can "gift" the fruits of these labors away-for an enormous fee-to a privileged few whom science has alchemically certified to be the bona fide parents in each case. Reproductive of life-itself, quietist toward concerns about life-in-particular, the innocent, discreet, 
quasi-humanitarian world of infertility medicine structurally obstructs political contestations based around what surrogate workers actually $d o$. Its internal apparatus leverages transnational distance (Ikemoto 2015), and notions of biogenetic property, to segregate surrogate gestation from the concept of gestation simple.

A surrogates' movement would be in a powerful position to begin to insist on some degree of negotiation and co-operation with regard to the construction of parentage more widely. It seems an exercise in utopianism to suggest that humans should adopt "their own" children as a matter of course or, put differently, that children should have to be adopted shortly after birth by whatever members of a community are collectively agreed to be best suited to the role-a choice which may not be biologically obvious. (In many respects, and in ways that become clearer through social histories of birth, what happens routinely to newborns is a form of "adoption".) These are, however, serious questions that could be native to a fully fledged politics of surrogacy. Conceivably, surrogates could lobby brokering clinics to rule out the anonymity and distance of the "reproductive tourism" approach, thus gesturing at a model of more mutualist or common childcare. In short, a politics of surrogacy could take what surrogate workers do seriously. Furthermore, it should go without saying that the de-naturalization of reproductive geography's gross unevenness is a task for every engaged scholar and onlooker, not only those who actually do the "assisting". However, surrogates who show themselves ready to disrupt and interrupt the terms, not to say the term, of outsourced gestation, despite the means of getting safe abortions residing in the hands of private experts, urgently require our support and solidarity. We are in no danger of running out of onlookers who will vocally characterize surrogacy transactions as baby-milling, baby-googling, baby-selling, baby-brokering, babyfarming, or indeed any combination of "baby" with a verb from the sphere of exchange. Like contemporary talk of "rent-a-wombs" and outcries about "test-tube babies" in the 1980s, such characterizations overwhelmingly fail to spell out the meat of their denunciation, which is merely implied by the neologism. The advancing frontier of commodification elicits recoil; as though denying that the most precious things should be for sale changes the fact that - exploitatively, yet consensually - they are.

If politics from below is to occur in the field of kinship production and, specifically, the biomedical industry of surrogacy, it shall be the specific and situated forms life takes - in and outside the womb-that matter. The question of consciously transforming the global mode of social 
reproduction, uninterrogated in surrogacy contracts, calls out to be animated and answered. What kind of lives should we collaboratively bring forth? How should we do so? Whose procreation needs and deserves assistance? How much emphasis should we place on having kids? Once we have evacuated the biomedical alchemists and their anti-political apparatus of sentimentality from the (expanded) gestational workplace, asking such questions about the individual and collective life-forms that we want to reproduce-and those we want to refuse to reproduce-actually becomes possible. It is incumbent on anyone commenting on this field to seek to determine how we could organize procreative assistance in such a way that de-privatizes procreation, centers the interests and the knowledge of gestational laborers, contests the uneven geographies of bioavailability, and undermines the global divisions of labor that stratify social reproduction.

\section{Acknowledgments}

In addition to the editors of this volume, I thank Noel Castree, Erik Swyngedouw, and Willie Osterweil for their help with my research and preparation of this text.

\section{Notes}

1. Anecdotal evidence pointed to a subsequent upsurge in reproductive tourism to Mexico (Parry 2015).

2. Available evidence suggests it is more common in non-commercial (or "altruistic") surrogacy for all parties to be members of the same local geographic, religious, racial, ethnic, or national grouping.

3. Octavia Orchard, a commissioning parent quoted in The Daily Mail, "Our rent-a-womb child from an Indian baby farm", 31 August 2012.

4. Notably, Rosi Braidotti, in "The Politics of "Life Itself" and New Ways of Dying" in New Materialisms, ed. Diana Coole and Samantha Frost. Duke University Press, 2010.

\section{BibLIOGRAPHY}

Alaimo, Stacy. 2010. Bodily Natures: Science, Environment, and the Material Self. Bloomington: Indiana University Press.

Anderson, Elizabeth. 1990. "Is Women's Labor a Commodity?" Philosophy \& Public Affairs 17(1): 71-92. 
Banerjee, Amrita. 2014. Race and a Transnational Reproductive Caste System: Indian Transnational Surrogacy. Hypatia 29(1): 113-128.

Berend, Zsuzsa. 2012. The Romance of Surrogacy. Sociological Forum 27(4): 913-936.

Cooper, Melinda, and Catherine Waldby. 2014. Clinical Labor: Tissue Donors and Research Subjects in the Global Bioeconomy. Durham: Duke University Press.

Ekman, Kajsa. 2013. Being and Being Bought: Prostitution, Surrogacy and the Split Self. Melbourne: Spinifex Press.

Federici, Silvia. 1975. Wages For Housework, Wages For Housework Committee (1975).

. 2004. Caliban and the Witch. New York: Autonomedia.

Fixmer-Oraiz, Natalie. 2013. Speaking of Solidarity: Transnational Gestational Surrogacy and the Rhetorics of Reproductive (In)Justice. Frontiers: A Journal of Women Studies 34(3): 126-163.

Franke, Katherine M. 2001. Theorizing Yes: An Essay on Feminism, Law, and Desire. Columbia Law Review 101(1): 181-208.

Gusmaroli, Danielle. 2015. Thai Surrogate Tells How Baby Gammy's White Skin Makes Him Stand Out and Neighbors Call Him "Farang" (Foreigner). The Daily Mail Australia, January 8. http://www.dailymail.co.uk/news/article-2932 144/I-tell-s-albino-don-t-repeat-painful-drama-Thai-surrogate-tellsbaby-Gammy-s-white-complexion-makes-stand-neighbours-call-farang-foreigner.html.

Haraway, Donna J. 1991. Simians, Cyborgs, and Women: The Reinvention of Nature. New York: Routledge.

—. 2011. Speculative Fabulations for Technoculture's Generations. Australian Humanities Review 50: 95-118.

Hawley, Samantha. 2014. Baby Gammy Story Takes Startling Turn as Extreme Options Revealed. Australian Broadcasting Corporation, August 17. http:// www.abc.net.au/7.30/content/2014/s4089822.htm.

Holmes, Oliver. 2015. Gay Parents Fight to Leave Thailand with Surrogate Baby Daughter. The Guardian, July 20. http://www.theguardian.com/world/2015/ jul/20/gay-parents-fight-to-leave-thailand-with-surrogate-baby-daughter.

Indian Council of Medical Research (ICMR) http://icmr.nic.in, accessed 2015-03-14.

Ikemoto, Lisa Chiyemi. 2015. Egg Freezing, Stratified Reproduction and the Logic of Not. Journal of Law and the Biosciences 2(1): 112-117.

Kirby, Jeffrey. 2014. Transnational Gestational Surrogacy: Does It Have to Be Exploitative? The American Journal of Bioethics 14(5): 24-32.

Klein, Renate. 1991. Women as Body Parts in the Era of Reproductive and Genetic Engineering. Healthcare for Women International 12(4): 393-405.

Lewis, Sophie. 2015. Book Review: Luc Boltanski, Transl. Catherine Porter, The Foetal Condition: A Sociology of Engendering and Abortion. Feminism \& Psychology 25(4): 1-5. 
2016. The Doyenne of Surrogacy on TV: Dr Patel's Mediations of Contract Pregnancy's Uneven Geographies.

Majumdar, Anindita. 2014. Nurturing an Alien Pregnancy: Surrogate Mothers, Intended Parents and Disembodied Relationships. Indian Journal of Gender Studies 21(2): 199-224.

Marks, Kathy. 2015. Baby Gammy: Australian Father Who Abandoned Down Syndrome Surrogate Child Now Tries to Access Funds Donated for His Care. The Independent, May 20. http://www.independent.co.uk/news/world/australasia/baby-gammy-australian-father-who-abandoned-down-syndromesurrogate-child-now-tries-to-access-funds-donated-for-his-care-10261916.html.

Michael, Sarah. 2015. Inside the Life of the Birth Mum. The Daily Mail, August 8. www.dailymail.co.uk/news/article-2718974/Inside-life-Gammys-birthmother-surrogacy-row.html.

Mies, Maria, and Vandana Shiva. 1993. People or Population: Towards a New Ecology of Reproduction. In Ecofeminism, ed. Maria Mies, and Vandana Shiva. London: Zed Books.

Murdoch, Lindsay. 2014. Australian Couple Leaves Down Syndrome Baby With Thai Surrogate. Sydney Morning Herald, August 1. http://www.smh.com.au/ national/australian-couple-leaves-down-syndrome-baby-with-thai-surrogate20140731-zz3xp.html.

O'Brien, Mary. 1981. The Politics of Reproduction. London: Routledge and Kegan Paul.

Parry, Bronwyn. 2015. Narratives of Neoliberalism: "Clinical Labor" in Context. Medical Humanities 41: 31-37.

Ragoné, Helena. 2003. The Gift of Life. In Surrogate Motherhood: International Perspectives, ed. Rachel Cook, and Shelley Day Sclater, 209-226. Oxford: Hart Publishing.

Rawlinson, Kevin. 2014. Interpol investigates "baby factory" as man fathers 16 surrogate children. The Guardian, 23rd August. https://www.theguardian. com/lifeandstyle/2014/aug/23/interpol-japanese-baby-factory-man-fathered16-children.

Roberts, Dorothy E. 2009. Race, Gender, and Genetic Technologies: A New Reproductive Dystopia? Signs: Journal of Women in Culture and Society 34(4): 783-804.

Rose, Nikolas. 2007. Politics of Life Itself Biomedicine, Power, and Subjectivity in the Twenty-First Century. Princeton: Princeton University Press.

Ross-Sheriff, Fariyal. 2012. Transnational Cross-Racial Surrogacy: Issues and Concerns. Affilia 27(2): 125-128.

Rudrappa, Sharmila. 2015. Discounted Life: The Price of Global Surrogacy in India. New York: New York University Press.

Stormer, Nathan. 2008. Looking in Wonder: Prenatal Sublimity and the Commonplace "Life". Signs: Journal of Women in Culture and Society 33(3): 647-473. 
Strathern, Marilyn. 1992. Reproducing the Future: Essays on Anthropology, Kinship and the New Reproductive Technologies. Manchester: Manchester University Press.

Teman, Elly. 2009. Embodying Surrogate Motherhood: Pregnancy as a Dyadic Body-Project. Body \& Society 15(3): 47-69.

Vora, Kalindi. 2009. Indian Transnational Surrogacy and the Commodification of Vital Energy. Subjectivity 28: 266-278.

- 2015. Life Support: Biocapital and the New History of Outsourced Labor. Minneapolis, MN: University of Minnesota Press. 